\title{
Article \\ Cladosporium sp. Isolate as Fungal Plant Growth Promoting Agent
}

\author{
Iuliana Răut ${ }^{1}$, Mariana Călin ${ }^{1}$, Luiza Capră ${ }^{1}$, Ana-Maria Gurban ${ }^{1, * \mathbb{D}}$, Mihaela Doni ${ }^{1}\left(\mathbb{D}\right.$, Nicoleta Radu $^{1,2} \mathbb{D}$ and \\ Luiza Jecu 1 ,*
}

1 Biotechnology Department, National Institute for Research \& Development in Chemistry and Petrochemistry_ICECHIM, Spl. Independentei 202, 060021 Bucharest, Romania; iulia_rt@yahoo.com (I.R.); marriconstantin@yahoo.com (M.C.); luizacapra@yahoo.com (L.C.); mihaela.badea@icechim.ro (M.D.); nicolbiotec@yahoo.com (N.R.)

2 Faculty of Biotechnology, University of Agronomic Sciences and Veterinary Medicine of Bucharest, 59 Mărăşti Boulevard, 011464 Bucharest, Romania

* Correspondence: amgurban@yahoo.com (A.-M.G.); jecu.luiza@icechim.ro (L.J.); Tel.: +40-0213163063 (L.J.)

check for updates

Citation: Răut, I.; Călin, M.; Capră, L.; Gurban, A.-M.; Doni, M.; Radu, N.; Jecu, L. Cladosporium sp. Isolate as Fungal Plant Growth Promoting Agent. Agronomy 2021, 11, 392. https://doi.org/10.3390/agronomy 11020392

Academic Editor: Yoshiharu Fuji

Received: 21 January 2021

Accepted: 18 February 2021

Published: 23 February 2021

Publisher's Note: MDPI stays neutral with regard to jurisdictional claims in published maps and institutional affiliations.

Copyright: (C) 2021 by the authors Licensee MDPI, Basel, Switzerland. This article is an open access article distributed under the terms and conditions of the Creative Commons Attribution (CC BY) license (https:/ / creativecommons.org/licenses/by/ $4.0 /)$.

\begin{abstract}
Cladosporium species are active in protecting plants against different biotic and abiotic stresses. Since these species produced a wide range of secondary metabolites responsible for the adaptation to new habitats, plant health and performance, they are of great interest, especially for biostimulants in agriculture. Cladosporium sp. produces protein hydrolysates (PHs), a class of biostimulants, by cultivation on medium with keratin wastes (feathers) as carbon and energy sources. The aim of this study was to select a Cladosporium isolate with potential to be used as plant growth promoting agent. The characteristics of Cladosporium isolates as plants biostimulants were evaluated through several tests, such as: antagonism versus plants pathogens, effect on plant growth of secreted volatiles produced by isolates, secretion of hydrolytic enzymes, production of 3-indole acetic acid, zinc and phosphorous solubilization, capacity to promote tomato seedlings growth (pot experiments). Cladosporium isolate T2 presented positive results to all tests. Encouraging results were obtained treating tomato seedlings with PHs from isolate Cladosporium T2 cultured on medium supplemented with $1 \%(w / w)$ chicken feathers, for which growth parameters, such as stem weight, stem height, and root weight were significantly higher by $65 \%, 32 \%$, and $55 \%$, respectively, compared to those treated with water.
\end{abstract}

Keywords: biostimulants; Cladosporium; feathers; protein hydrolysates; plant growth promoting agent

\section{Introduction}

Cladosporium species, endophytic fungi world widely distributed, are known to be active in protecting plants against different biotic and abiotic stresses. Based on the secretion of beneficial secondary metabolites, these species improve the ability of plants to adapt to new habitats and to sustain the plant health and performance. Among the secreted metabolites, a key role is played by gibberellins, hormones responsible for plant growthstimulating, especially in seed germination, stem elongation and leaf expansion [1-3]. Despite the colonization of internal plant tissues, Cladosporium species are not producing damages, and they are of great interest for specific medical effects, such as beneficial human health effects [4] and agro-industrial applications [5-8], as in the bioremediation and detergent industry [9] or in discoloration of textile dyes [10] and in the degradation of keratin containing wastes from natural environment [11,12].

Over the years, due to the increasing demand for better yield and quality of food and crops, the attention was focused on waste-derived biostimulants or raw organic material with biostimulant components [13-16]. Among biostimulants, protein hydrolysates (PHs) 
from fungal cultures carried out on medium with keratin wastes as a source of carbon and energy could be efficient in plants treatment for improving crop productivity and quality.

Keratin waste is an abundant and valuable resource, and its accumulation creates serious problems for the environment, only an efficient management will reduce soil and groundwater pollution. There are many possible applications of keratin waste for the reinforcement of cement, biopolymers, and composites, as well as in many biomedical applications $[17,18]$. Poultry feathers from processing chicken meat represent the most part of keratin waste and have become one of the major pollutants due to the recalcitrant nature of keratin [19]. Many restrictions prevent disposal methods and it is interesting to assess the potential of waste feathers in higher added-value applications. Keratin can be hydrolyzed by chemical treatment, or by hydrothermal process with the disadvantage of producing by-products of high toxicity to humans and environment. At the same time, keratin suffers severe degradation and destruction which affect further applications. The mild conditions of microbial degradation of keratin by keratinolytic microorganisms (fungi or bacteria) are considered an eco-friendly approach producing keratinases and reducing the amount of keratin waste [20-23]. The biodegradation process is efficient, with low costs and ensures the valorization of keratin waste while maintaining the valuable nutrient composition. The secreted keratinases have various applications in cosmetic, animal feed, detergents and agriculture [24].

The ability of Cladosporium to degrade the extensive disulfide crosslinking of keratin polypeptides and solubilize the keratin by secreting specialized enzymes can be used to obtain plant biostimulants, and recommends Cladosporium as a fungal agent to promote plant growth.

In view of the above facts, this study was designed to select a Cladosporium isolate with potential to be used as plant growth promoting agent. For this purpose, we analyzed the following issues: (i) To reveal the secretion of volatile organic compounds and the biocontrol activity against selected phytopathogens; (ii) to detect several significant abilities for a candidate as plant growth promoting agent, namely, phosphate and zinc solubilization activities, plant hormone production such as 3-indole acetic acid and the secretion of hydrolytic enzymes; and (iii) to assess Cladosporium sp. isolates as fungal agent for promoting plant growth through pot experiments. This combined analysis provided important information on the characteristics of Cladosporium isolate, which guided its application as plant biostimulants in agriculture.

\section{Materials and Methods}

\subsection{Microorganism}

Three Cladosporium soil isolates belonging to Microbial Collection of ICECHIM were used in the experimental study. The stock isolates were maintained on potato-dextrose-agar medium (PDA, Scharlau) and prior to use, their purity was controlled. The composition of the PDA medium was $\left(\mathrm{g} \cdot \mathrm{L}^{-1}\right)$ : 4 , peptone; 20 , glucose, 15 , agar; final $\mathrm{pH}=5.6$ at $25{ }^{\circ} \mathrm{C}$.

\subsection{Keratin Substrate}

Keratin powder was obtained as follows: chicken feathers from local poultry were cleaned, sterilized with $3 \%$ ethanol, vigorously washed and dried at $60{ }^{\circ} \mathrm{C}$. Following disinfection, the feathers were cut into small pieces for fungal cultivation. For use in keratinase assay as substrate, the feathers were grounded several times with a Retsch ball mill until they became a fine powder [25].

\subsection{Fungal Cultivation for Protein Hydrolysates (PHs) Preparation}

Cultivation in liquid medium was performed in Erlenmeyer agitated flasks on rotary incubator shaker Heidolph Unimax 1010, at $26 \pm 2{ }^{\circ} \mathrm{C}$ for 21 days. The mineral basal medium had the following composition $\left(\mathrm{g} \cdot \mathrm{L}^{-1}\right)$ : $0.1, \mathrm{KH}_{2} \mathrm{PO}_{4} ; 0.1, \mathrm{CCl}_{2} ; 0.1, \mathrm{FeSO}_{4} \times 7 \mathrm{H}_{2} \mathrm{O}$; $0.005, \mathrm{ZnSO}_{4} \times 7 \mathrm{H}_{2} \mathrm{O}$. The culture medium was supplemented with $1 \%$ feathers (processed as above, cut into small pieces), as a sole source of carbon and nitrogen and inoculated with 
$5 \mathrm{~mL}$ of each preculture. After incubation, the culture broth was filtered and supernatants were tested in experiments.

\subsection{Antagonism versus Plants Pathogens}

Cladosporium isolates were in vitro tested for antagonistic activity by dual culture technique on PDA plates [26]. Four plant pathogens purchased from Deutsche Sammlung von Mikroorganismen und Zellkulturen GmbH (DSMZ) were tested: Rhizoctonia solani, Fusarium graminearum, Sclerotinia sclerotiorum, and Botrytis allii. Briefly, PDA medium poured in sterile Petri plates was incubated with $5 \mathrm{~mm}$ culture disc of isolate and each pathogen. Antagonist activity was observed after incubation at $25 \pm 1{ }^{\circ} \mathrm{C}$, for $3-5$ days. The inhibition range was determined with the formula:

$$
I(\%)=(M-P) / M \times 100,
$$

where $I=$ inhibition; $M=$ diameter colony for the control of pathogen; $P=$ colony diameter of pathogen in dual cultures in the presence of antagonist. Three independent experiments were carried out.

\subsection{Evaluation of Tomato Growth Promotion by Volatiles Produced by Isolates}

The tests were carried out with tomato seeds (Solanum lycopersicum) purchased from Agrosem (Tg-Mureş, Romania). The seeds were surface sterilized by soaking in $75 \%$ ethanol and immersion in 3\% sodium hypochlorite. The fungal isolates were cultured on potato dextrose agar medium (Scharlau). The test was carried out in Magenta flasks [27], as follows: $1 \mathrm{~mL}$ of PDA medium was placed in each of the 12 glass bottles, and of these, only 9 bottles were inoculated with $10 \mu \mathrm{L}$ sporal suspension containing $10^{5} \mathrm{ufc} / \mathrm{mL}$ of Cladosporium isolates, three bottles for each isolate, and three for control, without microorganism. The bottles were sealed with biological filters that restrict the movement of conidia, but not volatiles. Plant growth was monitored and compared with controls grown without fungal cultures. The measured growth parameters included the total height and weight of the fresh stem, the weight of the root system and the number of leaves.

\subsection{Enzymatic Activities}

(1) Chitinase activity was evaluated by qualitative method with colloidal chitin as carbon source [28]. The culture medium had the following composition $\left(\mathrm{g} \cdot \mathrm{L}^{-1}\right): 4.5$, colloidal chitin; 0.3, $\mathrm{MgSO}_{4} \mathrm{X} 7 \mathrm{H}_{2} \mathrm{O} ; 3.0,\left(\mathrm{NH}_{4}\right)_{2} \mathrm{SO}_{4} ; 2.0, \mathrm{KH}_{2} \mathrm{PO}_{4} ; 1.0$, citric acid; 15.0, agar; 0.15 , bromcresol purple; $200 \mu \mathrm{L}$, Tween 80 . The Petri plates were central inoculated, as follows: (i) liquid culture filtrate $(20 \mu \mathrm{L})$ of each Cladosporium isolate grown on medium with or without feathers, and, (ii) spore suspension from Cladosporium culture on PDA medium, respectively. A $1 \mathrm{~mL}$ spore suspension contained approx. $1 \times 10^{5}$ spore $\mathrm{mL}^{-1}$. The Petri plates were incubated at $26 \pm 2{ }^{\circ} \mathrm{C}$ for seven days. The appearance of red-violet color was considered a positive result. Three replicates were made in all experiments.

(2) Cellulase activity was evaluated by the qualitative method with carboxymethylcellulose (CMC) as a cellulosic substrate [29]. The solid medium had the following composition $\left(\mathrm{g} \cdot \mathrm{L}^{-1}\right)$ : 1 , yeast extract; $5, \mathrm{CMC} ; 15$, agar. The Petri plates were inoculated and incubated as in the chitinase assay. After incubation, the plates were stained with Lugol's solution or Congo red $(0.1 \%)$, respectively, for $15 \mathrm{~min}$, at $26 \pm 2{ }^{\circ} \mathrm{C}$. The formation of a transparent circular area around fungal colony was considered a positive result. Three replicates were made.

(3) Keratinase activity was evaluated by the qualitative method using ball-milled feathers powder as an enzymatic substrate $[25,30]$. Chicken feathers were disinfected with $70 \%(v / v)$ ethylic alcohol, rinsed with sterile distilled water, dry overnight at $50{ }^{\circ} \mathrm{C}$, and finally, milled in ball mill Retsch (Model MM400, Germany). The solid medium had the following composition $\left(\mathrm{g} \cdot \mathrm{L}^{-1}\right)$ : 10 , feathers; $0.1, \mathrm{KH}_{2} \mathrm{PO}_{4} ; 0.01, \mathrm{CaCl}_{2} ; 0.1, \mathrm{FeSO}_{4} \mathrm{X} 7 \mathrm{H}_{2} \mathrm{O}$; $0.005, \mathrm{ZnSO}_{4} \times 7 \mathrm{H}_{2} 0 ; \mathrm{pH}=7$. The Petri plates were inoculated and incubated as in chitinase 
assay. Fungal growth was evaluated by measuring the colony diameter after, respectively, five and 10 days. Three replications were made.

\subsection{Colorimetric Assay for 3-Indole Acetic Acid (IAA) Production}

A colorimetric assay was used for IAA production at Cladosporium isolates [31]. Two compositions of culture medium were used $\left(\mathrm{g} \cdot \mathrm{L}^{-1}\right)$ : (i) PDB medium (potato-dextrosebroth, Scharlau), as control; (ii) PDB medium supplemented with L-tryptophan $\left(0.1 \mathrm{~g} \cdot \mathrm{L}^{-1}\right)$. The flasks inoculated with the fungal mycelium fragment were incubated for 8 days, at $26 \pm 2{ }^{\circ} \mathrm{C}$, on Heidolph Unimax 1010 (Heidolph Instruments $\mathrm{GmBH}$ and $\mathrm{Co}$, Germany) at $130 \mathrm{rpm}$. After centrifugation at $4000 \mathrm{rpm}, 15 \mathrm{~min}$, at $4{ }^{\circ} \mathrm{C}, 2 \mathrm{~mL}$ of each collected supernatant were treated with two drops of ortho-phosphoric acid. The positive result is considered the appearance of pink color in test slants. The quantification was made using the absorbance measured at $530 \mathrm{~nm}$ wavelength, on BioMate 3 (Thermo Spectronic, USA) [32], by reference to the calibration curve drawn with commercial IAA (Sigma Aldrich). Three replications were made.

\subsection{In Vitro Zinc Solubilization Assessment Using Plate Assay}

The fungal isolate was tested for its zinc solubilizing ability using an insoluble zinc compound, as $\mathrm{ZnO}$ [33]. The cultivation medium had the following composition $\left(\mathrm{g} \cdot \mathrm{L}^{-1}\right): 10$, dextrose; $1, \mathrm{NH}_{4} \mathrm{SO}_{4} ; 0.2, \mathrm{KCl} ; 0.2, \mathrm{~K}_{2} \mathrm{HPO}_{4} ; \mathrm{MgSO}_{4} \mathrm{X7H}_{2} \mathrm{O} ; 1, \mathrm{ZnO} ; 15$, agar. The medium was distributed into Petri plates and then inoculated with $5 \mathrm{~mm}$ mycelium fragment from fungal culture. The inoculated plates were incubated in the dark at $26 \pm 2{ }^{\circ} \mathrm{C}$, for seven days, in order to observe clear halo area around the colonies. The diameter of the clear zone was recorded. Three replicates were made.

\subsection{In Vitro Phosphate Solubilization Assessment Using Plate Assay}

Phosphate solubilization was qualitatively determined [34]. Cladosporium isolates were cultured in medium with the following composition $\left(\mathrm{g} \cdot \mathrm{L}^{-1}\right)$ : $0.3, \mathrm{MgSO}_{4} \mathrm{X} \mathrm{H}_{2} \mathrm{O}$;

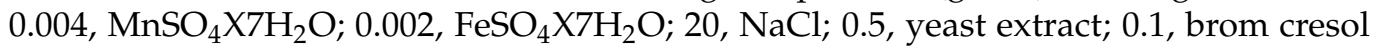
purple as $\mathrm{pH}$ indicator; $5.0, \mathrm{Ca}_{3}\left(\mathrm{PO}_{4}\right)_{2} ; 16$, agar; $\mathrm{pH}=7.0$. The Petri plates were inoculated with $5 \mathrm{~mm}$ mycelia fragments from fresh cultures and incubated for five days, at $26 \pm 2{ }^{\circ} \mathrm{C}$. The phosphate solubilization was confirmed by the formation of the clearing zone around the colonies. Three replications were made.

\subsection{Nitrogen Content of Protein Hydrolysates}

The supernatants were analyzed for nitrogen content according to the Kjeldhal method [35], using SR EN 15475:2009, EN 15558:2009 and EN 15558:2009 protocols. The analytical system (Behrotest $S 4{ }^{\circledR}$ WD 40, Behr Labor-Technik, Dusseldorf, Germany) comprises: infrared rapid digestion equipment, process suction automatic scrubber for neutralization of $\mathrm{H}_{2} \mathrm{SO}_{4}$ vapors and a fully automatic steam distillation equipment. The total protein content was calculated by multiplying the protein nitrogen concentration by a factor of 6.25 .

\subsection{Test In Vivo for the Capacity to Promote Tomato Seedlings Growth (Pot Experiments)}

Tomato seeds (Solanum lycopersicum) were planted in multicellular trays and incubated in the growth chamber under controlled conditions (Micro Clima Series TM, Labs Economic Lux chamber, Snijders, Netherlands). The parameters were set at the following values: humidity about $69 \% ; 26{ }^{\circ} \mathrm{C}$ as the day temperature and $22{ }^{\circ} \mathrm{C}$ as the night temperature; 10,000 lux; day /night cycle as $16 \mathrm{~h}$ per day $/ 8 \mathrm{~h}$ per night. Four multicellular trays ( 12 cells per tray) were used for each type of treatment and also for control. All treatments were performed with $1 \mathrm{~mL}$ of protein hydrolysates filtrate obtained from the culture liquid after filtration with a $0.2 \mu \mathrm{m}$ filter, over a period of 1 month. The treatments were applied at weekly intervals. The control trays were treated with water. Additonally, mineral medium was used for the treatment of corresponding pots. After 1 month, the tomato seedlings were carefully collected from the multicellular trays and the root was cleaned with tap 
water for several times, in order to analyze the planned growth parameters. The growth parameters of the treated tomato seedlings were compared with the untreated ones [36].

\subsection{Statistical Analysis}

The data obtained in each experimental variant were analyzed with GraphPad Prism 5.0 software. All parameters (Standard Error, $\mathrm{p}$ value) were calculated using a confidence interval of $95 \%$. Results are presented as standard error bars and respectively as " $p$ " values. In the case of $p$ parameter were used the following significances and notations: $p<0.05=$ insignificant differences; notation: ${ }^{*}$ for $0.05<p<0.01=$ significant differences between the experimental variant and Control; notation: ${ }^{* *}$ for $0.01<p<0.005$ $=$ distinct significant differences between the experimental variant and Control; notation: $* * *$ for $p<0.005=$ highly significant differences between the experimental variant and Control.

\section{Results}

\subsection{Antagonism versus Plant Pathogens}

The tests were carried out in Petri plates using several plant pathogens such as: F. graminearum, S. sclerotiorum, B. allii, and R. solani, the results being presented in Figure 1 and respectively in Table 1.

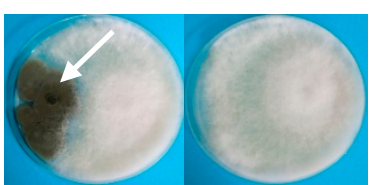

F. graminearum

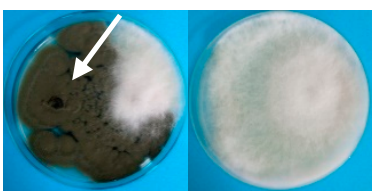

F. graminearum

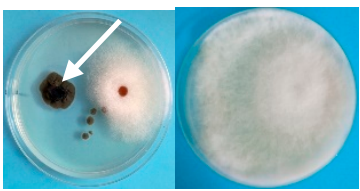

F. graminearum

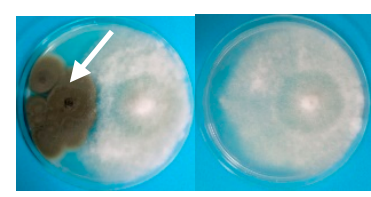

B. allii
(a)Activity ofCladosporium T1 (arrow-culture of isolate T1)

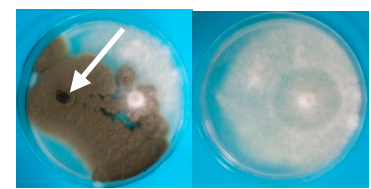

B. allii

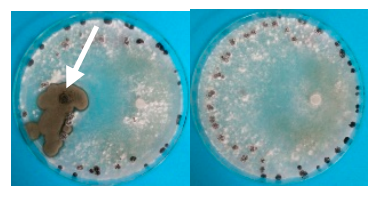

S. sclerotiorum

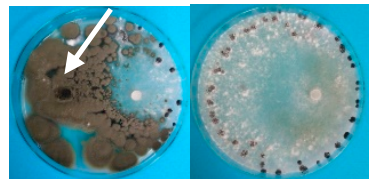

S. sclerotiorum

(b)Activity ofCladosporium T2 (arrow-culture of isolate T2)

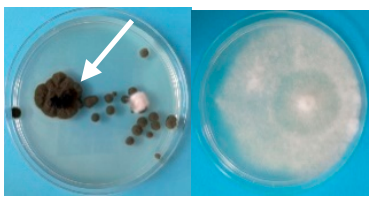

B. allii

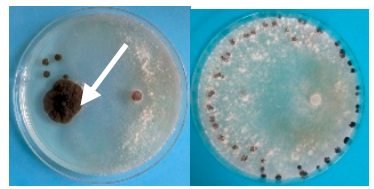

S. sclerotiorum

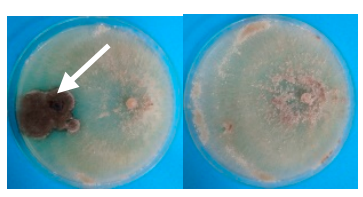

R. solani

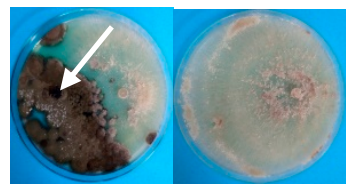

R. solani

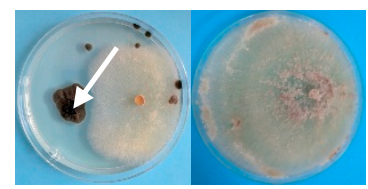

R. solani

(c)Activity ofCladosporium T3 (arrow-culture of isolate T3)

Figure 1. Antagonism of Cladosporium isolates versus plant pathogens. Pure fungal colonies of pathogens are presented as growth control.

Table 1. Inhibition of pathogens by Cladosporium isolates.

\begin{tabular}{ccccc}
\hline \multirow{2}{*}{$\begin{array}{c}\text { Antagonistic } \\
\text { Fungal Isolate }\end{array}$} & \multicolumn{4}{c}{ Inhibition * (\%) } \\
\cline { 2 - 5 } & F. graminearum & B. allii & S. sclerotiorum & R. solani \\
\hline Cladosporium sp. T1 & $35.6 \pm 0.5$ & $37.1 \pm 0.4$ & $40.8 \pm 0.9$ & $35.5 \pm 0.5$ \\
\hline Cladosporium sp. T2 & $\mathbf{5 7 . 4} \pm \mathbf{0 . 5}$ & $86.4 \pm 0.5$ & $\mathbf{6 2 . 6} \pm \mathbf{0 . 5}$ & $\mathbf{5 6 . 9} \pm \mathbf{0 . 9}$ \\
\hline Cladosporium sp. T3 & $47.1 \pm 0.4$ & $58.3 \pm 0.6$ & $29.2 \pm 0.4$ & $41.7 \pm 0.5$ \\
\hline
\end{tabular}

${ }^{*}$ Values are the average of three independent experiments \pm standard deviations. 
From all tested strains, Cladosporium T2 isolate was the most active against tested pathogens, $B$. allii, being most sensitive to antagonist isolate, with an inhibition rate of $86.4 \%$. This is a valuable information since Botrytis allii affects onions, garlic, and leeks, causing economical post-harvest damages, decreasing the storage durability and market value.

\subsection{Effects of Volatiles Secreted by Cladosporium Isolates}

Tomato seeds were exposed to volatiles produced by Cladosporium isolates and their effect upon germination process is presented in Figure 2. By emitting volatile blends, Cladosporium isolates mediated the growth of tomato plants as compared to control, where the seeds were treated with water. Thus, a much more vigorous growth was observed, with more robust stems and leaves, compared to the control seedlings not exposed to volatile compounds. For measuring the plant growth promotion under in vitro conditions, 21 days exposure duration have been used, being comparable with other similar studies carried out with tobacco plants [37].

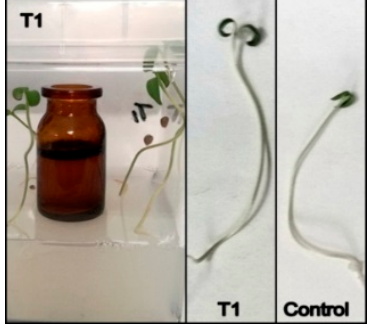

Exposure toT1 isolate

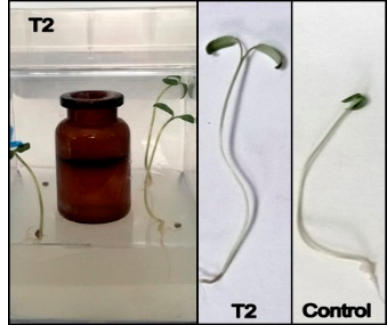

Exposure toT2 isolate

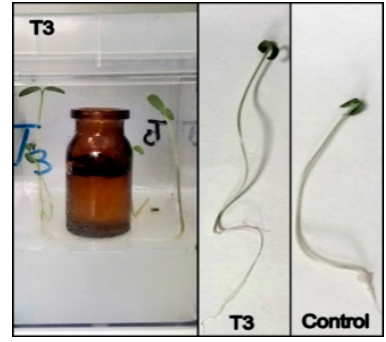

Exposure toT3 isolate

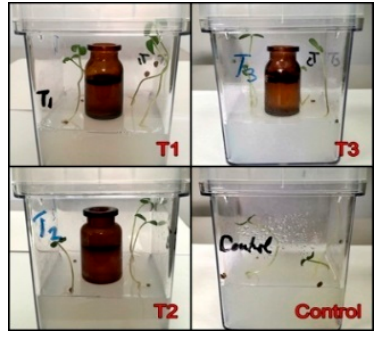

Exposure toall isolates

Figure 2. Growth promotion of tomato seedling by exposure to volatiles secreted by Cladosporium isolates. The photographs were taken 21 days after seed sowing.

After 21 days of exposure to volatiles secreted by Cladosporium, the individual plants presented certain increases as compared with controls. Thus, an equal increase of $50 \%$ for total plant weight at all fungal isolates was recorded compared to the control values. The percentage increase for plant height compared to control follows the descendent order: $28.5 \%$ for isolate $\mathrm{T} 2,>27 \%$ for isolate T3 and, respectively, $>25 \%$ at isolate $\mathrm{T} 1$. The highest values for plant height were obtained for T1 and T2 $(7.5 \mathrm{~cm}$; increase of $26 \%$ compared to control), followed by T3 $(6.8 \mathrm{~cm}$; increase of 19\%). Regarding the length of root system, the best results were found at isolate $\mathrm{T} 2(3.5 \mathrm{~cm})$, followed by isolate $\mathrm{T} 3(3.2 \mathrm{~cm})$, and isolate $\mathrm{T} 1(2.5 \mathrm{~cm})$, compared with the control values $(2.0 \mathrm{~cm})$. No significant difference between isolates was observed regarding the number of leaves (Table 2).

Table 2. Plant growth parameters after volatiles exposure.

\begin{tabular}{cccccc}
\hline & \multicolumn{3}{c}{ Growth Parameters * } \\
\cline { 2 - 6 } Fungal Isolate & Total Weight $\mathbf{( g )}$ & Total Height $\mathbf{( c m )}$ & Plant Height $\mathbf{( c m )}$ & $\begin{array}{c}\text { Root System } \\
\text { Length } \mathbf{( c m})\end{array}$ & $\begin{array}{c}\text { Number of } \\
\text { Leaves }\end{array}$ \\
\hline Cladosporium sp. T1 & $0.06 \pm 0.01$ & $10.0 \pm 0.3$ & $7.5 \pm 0.2$ & $2.5 \pm 0.2$ & $\begin{array}{c}\text { Two leaves of } \\
\text { medium size }\end{array}$ \\
\hline Cladosporium sp. T2 & $0.06 \pm 0.01$ & $\mathbf{1 0 . 5} \pm \mathbf{0 . 2}$ & $\mathbf{7 . 5} \pm \mathbf{0 . 4}$ & $\mathbf{3 . 5} \pm \mathbf{0 . 3}$ & $\begin{array}{c}\text { Two leaves of } \\
\text { medium size }\end{array}$ \\
\hline Cladosporium sp. T3 & $0.06 \pm 0.01$ & $10.3 \pm 0.3$ & $6.8 \pm 0.4$ & $3.2 \pm 0.2$ & $\begin{array}{c}\text { Two leaves of } \\
\text { medium size }\end{array}$ \\
\hline Control & $0.03 \pm 0.01$ & $7.5 \pm 0.2$ & $5.5 \pm 0.2$ & $2.0 \pm 0.3$ & $\begin{array}{c}\text { Two leaves of } \\
\text { small size }\end{array}$ \\
\hline
\end{tabular}

\footnotetext{
* Values are the average of three independent experiments \pm standard deviations.
} 


\subsection{Secretion of Hydrolytic Enzymes}

The presence of hydrolytic enzymes was highlighted in plate assay by inoculating the solid medium with mycelia fragments from isolates or filtrates from fungal cultivations in liquid media, with or without feathers (Figure 3). All enzymatic activities exhibited by isolate T2 were significantly higher compared to isolates T1 and T3, especially for cellulase activities where clearance zone (halo) after flooding with Lugol covered almost the entire plate (Figure 3c).

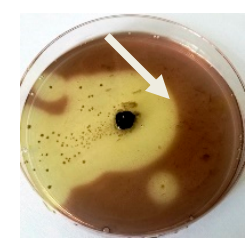

Cladosporium sp. T1

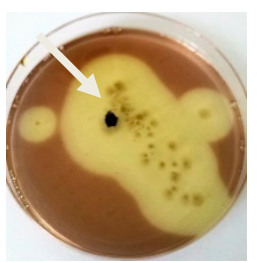

Cladosporium sp. T2

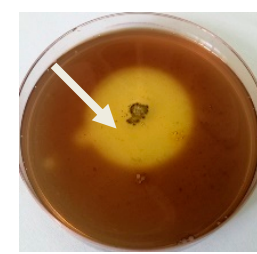

Cladosporium sp. T3

(a)Keratinase plate assay. Zone of clearance (halo) after flooding with iodine solution (Lugol).

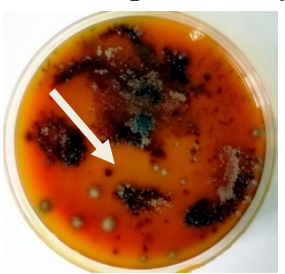

Cladosporium sp. T1

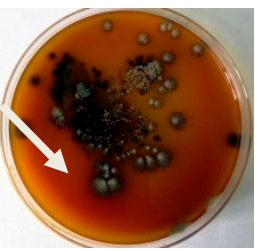

Cladosporium sp. T2

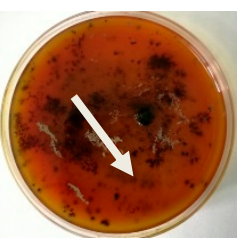

Cladosporium sp. T3

(b)Chitinase plate assay. Changing the color of culture medium from yellow to reddish brown, around the mycelium

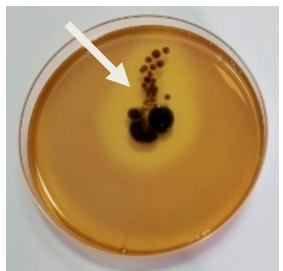

Cladosporium sp. T1

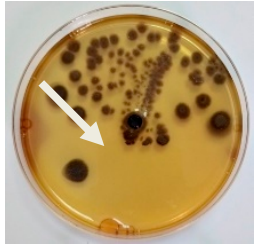

Cladosporium sp. T2

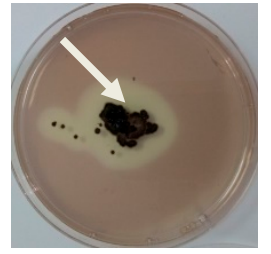

Cladosporium sp. T3

(c)Cellulases plate assay.Zone of clearance (halo) after flooding with iodine solution (Lugol)

Figure 3. Secretion of hydrolytic enzymes through plate assay inoculated with mycelia fragments at Cladosporium isolates (after 7 days of incubation).

Cladosporium isolate T2 grown on feathers medium exhibited the highest values of keratinase, chitinase, and cellulase, followed by isolate T3 (Table 3.).

Table 3. Colony diameter in plate assay inoculated with culture filtrates for detection of hydrolytic enzymes.

\begin{tabular}{cccc}
\hline \multirow{2}{*}{$\begin{array}{c}\text { Culture Filtrate from } \\
\text { Isolates }\end{array}$} & 0 & \multicolumn{3}{c}{ Colony Diameter (cm) * } \\
\cline { 2 - 4 } & Keratinase Activity & Chitinase Activity & Cellulase Activity \\
\hline $\begin{array}{c}\text { Cladosporium sp. T1 } \\
\text { (medium without feathers) }\end{array}$ & $2.6 \pm 0.05$ & $2.2 \pm 0.1$ & $0.6 \pm 0.05 \mathrm{~mm}$ \\
\hline $\begin{array}{c}\text { Cladosporium sp. T1 } \\
\text { (medium with feathers) }\end{array}$ & $0.7 \pm 0.05$ & $0.7 \pm 0.1$ & $2.2 \pm 0.05$ \\
\hline $\begin{array}{c}\text { Cladosporium sp. T2 } \\
\text { (medium without feathers) }\end{array}$ & & & $0.6 \pm 0.05$ \\
\hline
\end{tabular}


Table 3. Cont.

\begin{tabular}{cccc}
\hline \multirow{2}{*}{$\begin{array}{c}\text { Culture Filtrate from } \\
\text { Isolates }\end{array}$} & $\mathbf{3}$ Colony Diameter (cm)* \\
\cline { 2 - 4 } & Keratinase Activity & Chitinase Activity & Cellulase Activity \\
\hline $\begin{array}{c}\text { Cladosporium sp. T2 } \\
\text { (medium with feathers) }\end{array}$ & $\mathbf{4 . 3} \pm \mathbf{0 . 0 5}$ & $\mathbf{3 . 4} \pm \mathbf{0 . 0 9}$ & $\mathbf{3 . 1} \pm \mathbf{0 . 0 8}$ \\
\hline $\begin{array}{c}\text { Cladosporium sp. T3 } \\
\text { (medium without feathers) }\end{array}$ & $0.6 \pm 0.06$ & $0.8 \pm 0.05$ & $0.8 \pm 0.08$ \\
\hline $\begin{array}{c}\text { Cladosporium sp. T3 } \\
\text { (medium with feathers) }\end{array}$ & $3.2 \pm 0.00$ & $3.2 \pm 0.05$ & $2.4 \pm 0.09$ \\
\hline
\end{tabular}

${ }^{*}$ Values are the average of three independent experiments \pm standard deviations.

No keratinase and chitinase activities were obtained from Cladosporium isolate T1. As expected, the enzymatic activities exhibited by fungal isolates were higher in the medium containing feathers, considered a good source of carbon and energy. No clear zones were formed in tests carried out with filtrates from minimal culture medium and non-inoculated medium, as control.

\subsection{IAA Production}

The production of IAA was determined using a colorimetric method. Figure 4 shows that only Cladosporium isolate T1 failed to produce IAA, while the test results were positive for T2 and T3 isolates, highlighting the apperance of pink color.

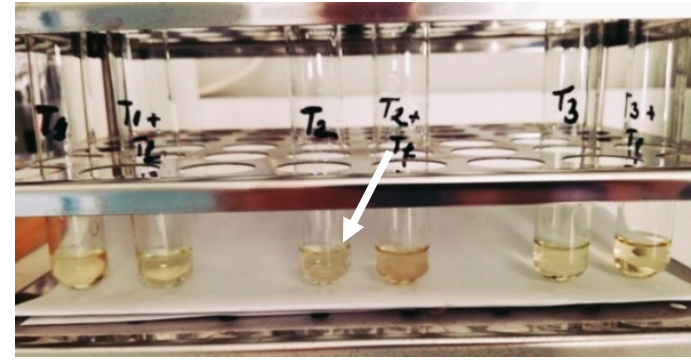

(a) Colorimetric test for IAA production

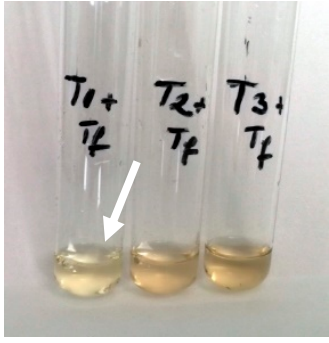

(b) PDB medium + L-tryptophan

Figure 4. Images of test for IAA production at fungal isolates (T1, T2, T3—supernatants from fungal cultivation on PDB medium; T1 + Tf, T2 + Tf, T3 + Tf-supernatants from fungal cultivation on PDB medium supplemented with L-tryptophan; arrow-pink color).

Cladosporium isolate $\mathrm{T} 2$ was about $62 \%$ more active in IAA production on PDB medium, and $22 \%$ on PDB + trytophan medium, respectively, compared to T3, while T1 isolate showed very low activity closer to control values (Table 4).

Table 4. Production of IAA by fungal isolates on culture media.

\begin{tabular}{ccc}
\hline Strain & $\begin{array}{c}\mathbf{D O}^{*}{ }_{\text {530 } \mathbf{~ n m}} \\
\text { (PDB Medium) }^{*}\end{array}$ & $\begin{array}{c}\text { DO }^{*} \text { 530 } \mathbf{n m} \\
\text { (PDB + L-Tryptophan) }^{\text {(PD }}\end{array}$ \\
\hline Cladosporium T1 & $0.014 \pm 0.001$ & $0.024 \pm 0.001$ \\
\hline Cladosporium T2 & $\mathbf{0 . 0 7 6} \pm \mathbf{0 . 0 0 2}$ & $\mathbf{0 . 1 2 5} \pm \mathbf{0 . 0 1 2}$ \\
\hline Cladosporium T3 & $0.047 \pm 0.001$ & $0.102 \pm 0.002$ \\
\hline Control (culture medium) & $0.010 \pm 0.002$ & $0.014 \pm 0.001$ \\
\hline
\end{tabular}

${ }^{*}$ Values are the average of three independent experiments \pm standard deviations.

\subsection{Capacity of Zinc and Phosphorus Solubilising}

The special features as a promoting agent for plant growth are the ability to solubilize zinc and phosphorus (Figure 5). The tests were performed on Petri plates on a specific 
media composition, $\mathrm{ZnO}$ and calcium phosphate, respectively. The activity for zinc solubilization of Cladosporium T2 isolate was higher compared to T1 and T3 isolates (Figure 5a). Regarding phosphorus solubilization, the differences between isolates were not significant, the images indicating almost the same zone of decoloration (Figure 5b).

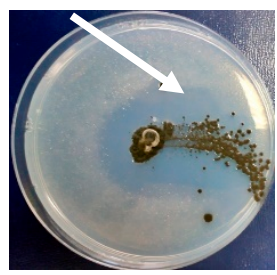

Cladosporium sp. T1

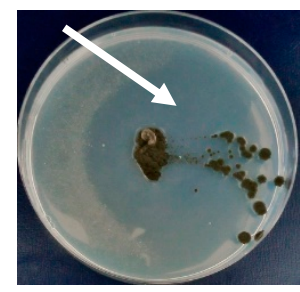

Cladosporium sp.T2

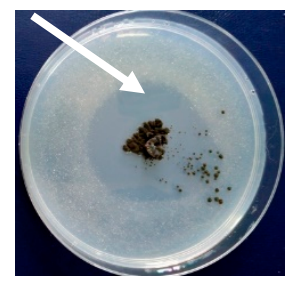

Cladosporium sp.T3

(a) $\mathrm{Zn}$ (as $0.1 \% \mathrm{ZnO}$ ) solubilization. Appearance of clear zone (halo) around mycelium, as $\mathrm{Zn}$ solubilization

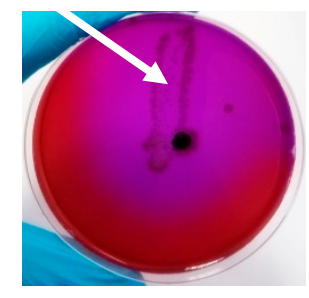

Cladosporium sp. T1

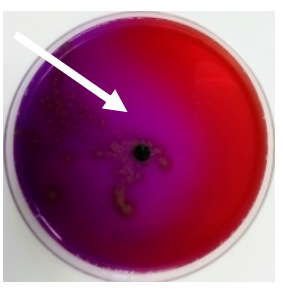

Cladosporium sp.T2

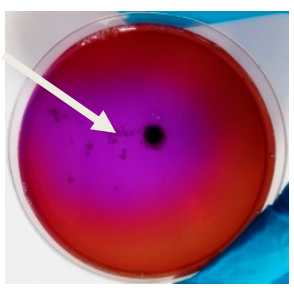

Cladosporium sp.T3

(b)Phosphorus (as Ca3 (PO4)2 solubilization. Large zone of decolorization in culture me-dium (changing the color in purple from red, around fungal colony.

Figure 5. Images of zinc and phosphorus solubilization at Cladosporium isolates (images after seven days of incubation).

\subsection{Nitrogen Content}

Useful data for the characterization of fungal protein hydrolysates were obtained from the analysis of organic and inorganic nitrogen content. Cultivation of Cladosporium T2 isolate on feathers medium led to protein hydrolysates with the highest level of ammonium and total nitrogen, $211 \times 10^{-3} \mathrm{mg} / \mathrm{mg}$, and $569 \times 10^{-3} \mathrm{mg} / \mathrm{mg}$, respectively, compared to other working options (Table 5.). Generally, the total nitrogen content of PHs obtained in medium with and without keratin source decreased in the following order: isolate T2 > isolate T1 > isolate T3, except for ammonium nitrogen in medium without feathers, where the value from $\mathrm{T} 3$ exceeded those obtained from $\mathrm{T} 1$.

Table 5. Nitrogen content of protein hydrolysates obtained from cultivation of Cladosporium isolates in experimental conditions $\left({ }^{*}\right)$.

\begin{tabular}{|c|c|c|c|c|c|c|}
\hline \multirow[t]{2}{*}{ Sample } & \multicolumn{2}{|c|}{$\begin{array}{c}\text { Total Nitrogen * } \\
\text { (Kjeldhal) (mg/mg) }\end{array}$} & \multicolumn{2}{|c|}{$\begin{array}{c}\text { Ammonium Nitrogen * } \\
(\mathrm{mg} / \mathrm{mg})\end{array}$} & \multicolumn{2}{|c|}{$\begin{array}{l}\text { Protein Nitrogen * } \\
(\mathrm{mg} / \mathrm{mg})\end{array}$} \\
\hline & $\begin{array}{l}\text { Medium } \\
\text { no } \\
\text { Feathers }\end{array}$ & $\begin{array}{l}\text { Medium with } \\
\text { Feathers }\end{array}$ & $\begin{array}{l}\text { Medium no } \\
\text { Feathers }\end{array}$ & $\begin{array}{l}\text { Medium with } \\
\text { Feathers }\end{array}$ & $\begin{array}{c}\text { Medium } \\
\text { no } \\
\text { Feathers }\end{array}$ & $\begin{array}{l}\text { Medium with } \\
\text { Feathers }\end{array}$ \\
\hline Cladosporium $\mathrm{T} 1$ isolate & $127 \times 10^{-3}$ & $137 \times 10^{-3}$ & $61 \times 10^{-3}$ & $87 \times 10^{-3}$ & $66 \times 10^{-3}$ & $50 \times 10^{-3}$ \\
\hline Cladosporium $\mathrm{T} 2$ isolate & $90 \times 10^{-3}$ & $569 \times 10^{-3}$ & $93 \times 10^{-3}$ & $211 \times 10^{-3}$ & $55 \times 10^{-3}$ & $358 \times 10^{-3}$ \\
\hline Cladosporium $\mathrm{T} 3$ isolate & $102 \times 10^{-3}$ & $120 \times 10^{-3}$ & $88 \times 10^{-3}$ & $87 \times 10^{-3}$ & $33 \times 10^{-3}$ & nd \\
\hline $\begin{array}{l}\text { Minimal basal } \\
\text { medium-Control }\end{array}$ & $80 \times 10^{-3}$ & $96 \times 10^{-3}$ & $60 \times 10^{-3}$ & $84 \times 10^{-3}$ & $20 \times 10^{-3}$ & $12 \times 10^{-3}$ \\
\hline
\end{tabular}

$\left(^{*}\right)$ Total nitrogen-Kjeldhal method; ammonium nitrogen calculated according to standard SR EN 15475:2009; protein nitrogen-calculated as total nitrogen minus ammonium nitrogen. 


\subsection{Pot Experiments with Tomato Seedlings Treated with Protein Hydrolysates from Cladosporium Cultures}

The growth parameters as plants height, shoots length and root weight of the treated tomato seedlings were compared with the untreated ones after 1 month of incubation in the growth chamber (Figure 6).

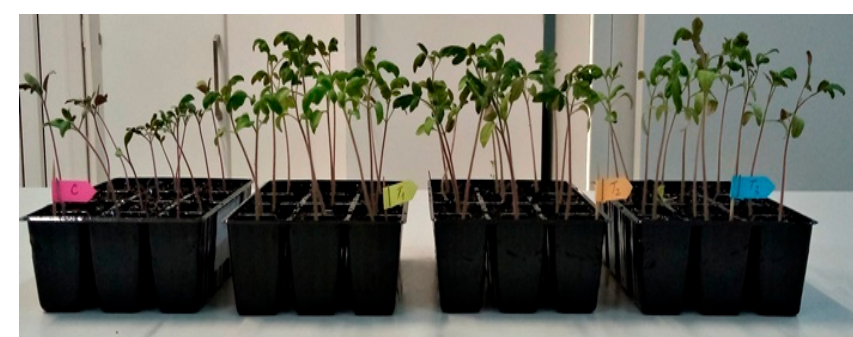

(a) Plants exposed to PHs from isolates cultured on medium without feathers

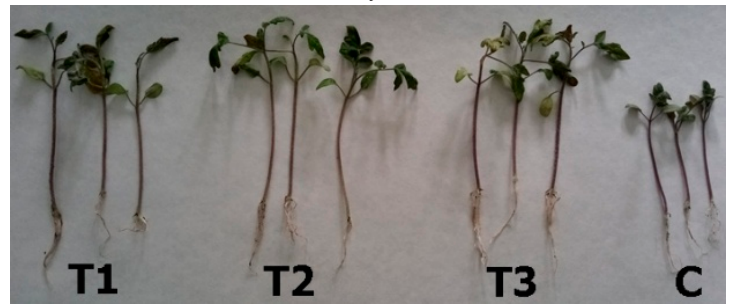

(c) Plants collected after 1 month of treatment with $\mathrm{PHs}$ from isolates grown on medium without feathers

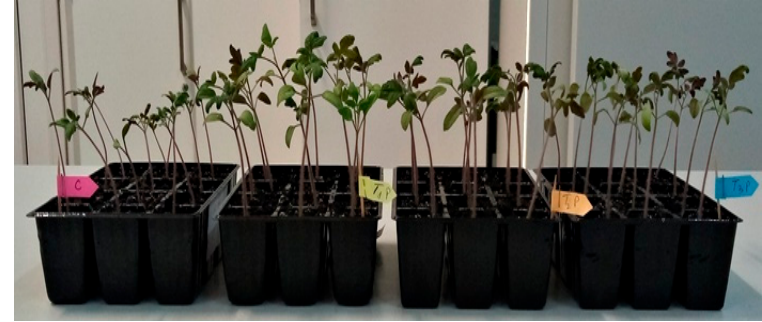

(b) Plants exposed to PHs from isolates cultured on medium with feathers

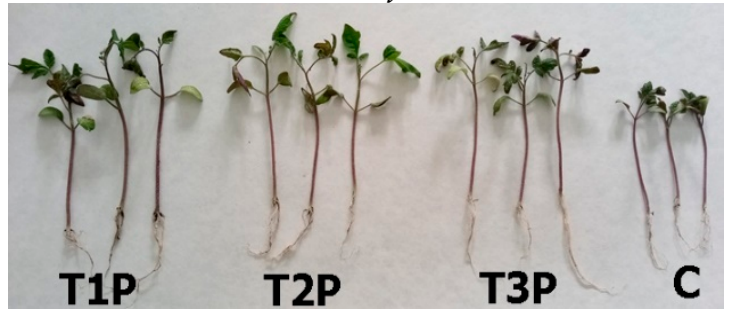

(d) Plants collected after 1 month of treatment with PHs from isolates grown on medium with feathers

Figure 6. Images of tomato plants treated with protein hydrolysates from Cladosporium isolates (fungal isolates T1, T2, and T3 cultured on medium without feathers; fungal isolates T1P, T2P and T3P cultured on medium with feathers; C-Control, treatment with tap water).

In pot experiments, all Cladosporium isolates presented a certain positive action on tomato seedlings by improving the growth parameters. Visual observations showed that tomato plants used as control, treated with water or minimal medium, are smaller compared to those treated with PHs (Table 6). Thus, the data demonstrate the performance of applying treatments with PHs compared to watering, by increasing the values of growth parameters (e.g., for stem height, $28 \%$ at $\mathrm{T} 1,32 \%$ at $\mathrm{T} 2$, and $30 \%$ at $\mathrm{T} 3$; for stem weight, $52 \%$ at $\mathrm{T} 1,65 \%$ at $\mathrm{T} 2$, and $55 \%$ at $\mathrm{T} 3$; for root weight, $55 \%$ for all isolates). As expected, the supplementation of culture medium with feathers leads to a high nitrogen content in the fungal culture filtrates, which brings benefits to plants growth, in our case, especially to rooted plant. For each fungal isolate, the values of the growth parameters were to a certain extent higher than those from culture media without feathers (e.g., for stem height, $5 \%$ at $\mathrm{T} 1,7 \%$ at $\mathrm{T} 2,9.4 \%$ at $\mathrm{T} 3$; for stem weight, 0 at $\mathrm{T} 1,15 \%$ at $\mathrm{T} 2,13.7 \%$ at $\mathrm{T} 3$; for root weight, $33 \%$ at $\mathrm{T} 1,22 \%$ at $\mathrm{T} 2$, and $22 \%$ at T3). It is important to highlight that the effects are more visible at root weight, the percentages are higher compared to other growth parameters. As a final conclusion of pot experiment, tomato plants treated with PHs from Cladosporium $\mathrm{T} 2$ isolate cultured on medium supplemented with feathers developed better. 
Table 6. Effects on tomato growth exposed to treatment with protein hydrolysates from Cladosporium isolates cultured on medium with or without feathers.

\begin{tabular}{cccc}
\hline $\begin{array}{c}\text { Protein Hydrolysates } \\
\text { Obtained from } \\
\begin{array}{c}\text { Cladosporium Cultures } \\
\text { Grown on Different Media }\end{array}\end{array}$ & $\begin{array}{c}\text { Stem Height } \\
\mathbf{( \mathbf { c m } )}\end{array}$ & $\begin{array}{c}\text { Stem Weight } \\
\mathbf{( g )}\end{array}$ & $\begin{array}{c}\text { Root Weight * } \\
\text { (g) }\end{array}$ \\
\hline $\begin{array}{c}\text { Isolate T1 } \\
\text { (medium without feathers) }\end{array}$ & $8.48 \pm 0.9$ & $0.49 \pm 0.09$ & $0.06 \pm 0.01$ \\
\hline $\begin{array}{c}\text { Isolate T1P } \\
\text { (medium with feathers) }\end{array}$ & $8.88 \pm 0.9$ & $0.48 \pm 0.09$ & $0.09 \pm 0.02$ \\
\hline $\begin{array}{c}\text { Isolate T2 } \\
\text { (medium without feathers) }\end{array}$ & $8.62 \pm 0.9$ & $0.55 \pm 0.08$ & $0.07 \pm 0.01$ \\
\hline $\begin{array}{c}\text { Isolate T2P } \\
\text { (medium with feathers) }\end{array}$ & $\mathbf{9 . 3 4} \pm \mathbf{0 . 7}$ & $\mathbf{0 . 6 5} \pm \mathbf{0 . 1}$ & $\mathbf{0 . 0 9} \pm \mathbf{0 . 0 3}$ \\
\hline $\begin{array}{c}\text { Isolate T3 } \\
\text { (medium without feathers) }\end{array}$ & $8.33 \pm 0.7$ & $0.44 \pm 0.08$ & $0.07 \pm 0.01$ \\
\hline $\begin{array}{c}\text { Isolate T3P } \\
\text { (medium with feathers) }\end{array}$ & $9.23 \pm 0.9$ & $0.51 \pm 0.08$ & $0.09 \pm 0.03$ \\
\hline Minimal medium (MM) & $6.73 \pm 0.8$ & $0.38 \pm 0.07$ & $0.06 \pm 0.02$ \\
\hline Control (water) & $6.37 \pm 0.9$ & $0.23 \pm 0.07$ & $0.04 \pm 0.02$ \\
\hline Values are the average of measurements of 12 plants randomly selected from multicellular trays \pm standard deviations.
\end{tabular}

\subsection{Statistic Analysis}

The treatment means of tomato seedlings performed in pot experiments were compared with GraphPadPrism 5.0 software. This statistical analysis provided important information about characteristics of Cladosporium isolates. Figure 7 provides that good results were obtained in tomato seedlings treatment with protein hydrolysates from $\mathrm{Cla}$ dosporium $\mathrm{T} 2$ isolate (T2P sample notation) cultured on medium supplemented with $1 \%$ feathers, being statistically significant. 


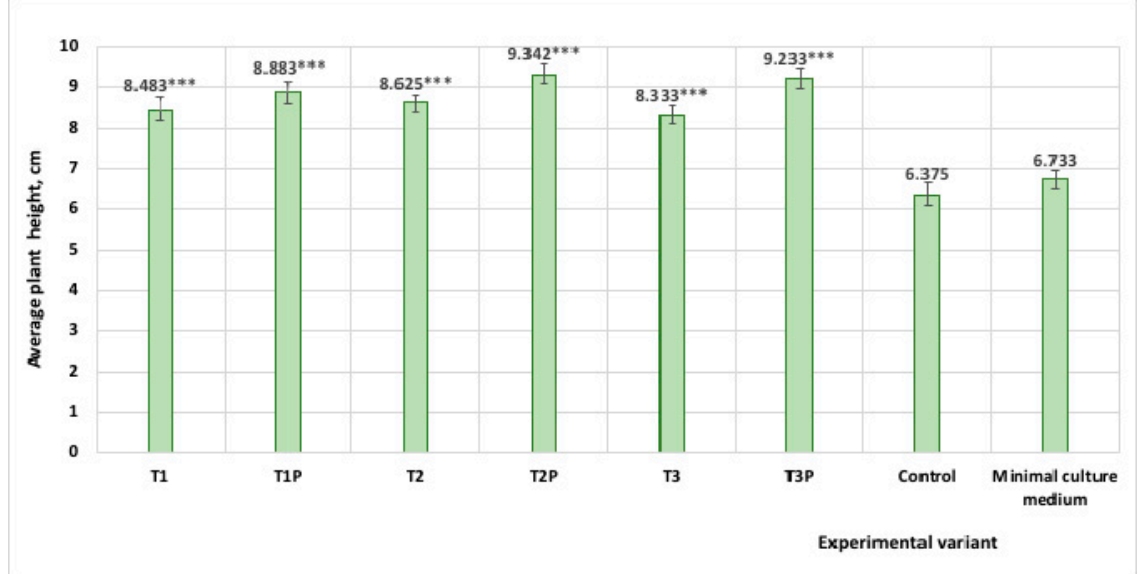

(a) The influence of experimental variants on stems height

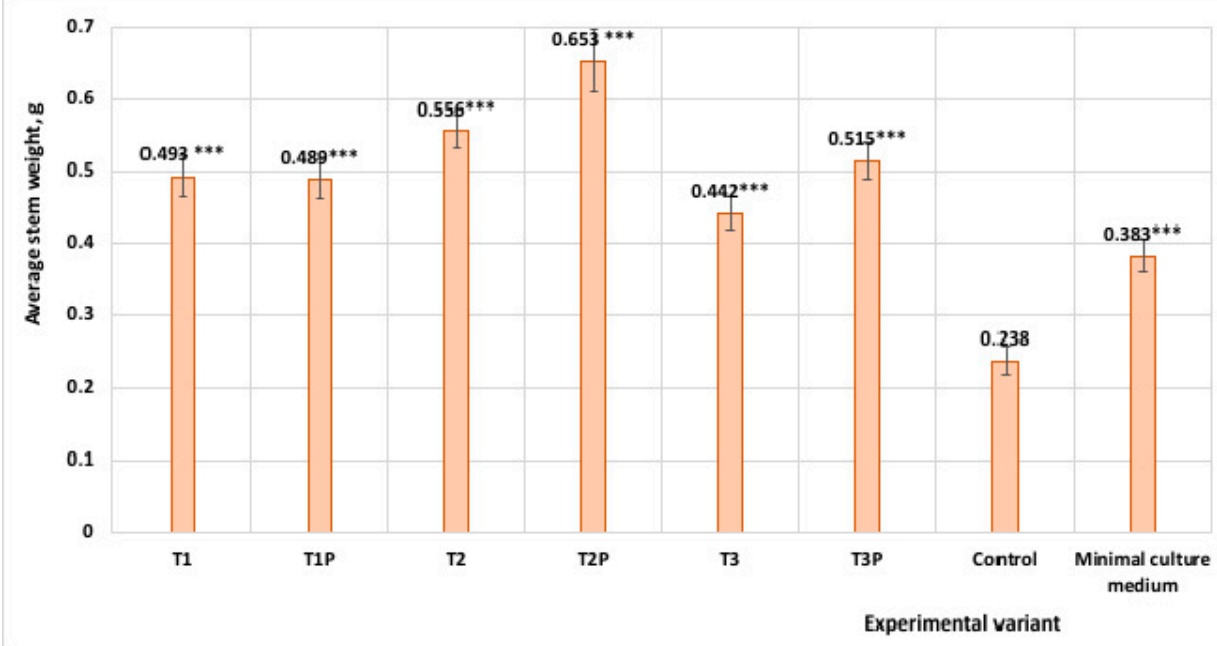

(b) The influence of experimental variants on stems weight

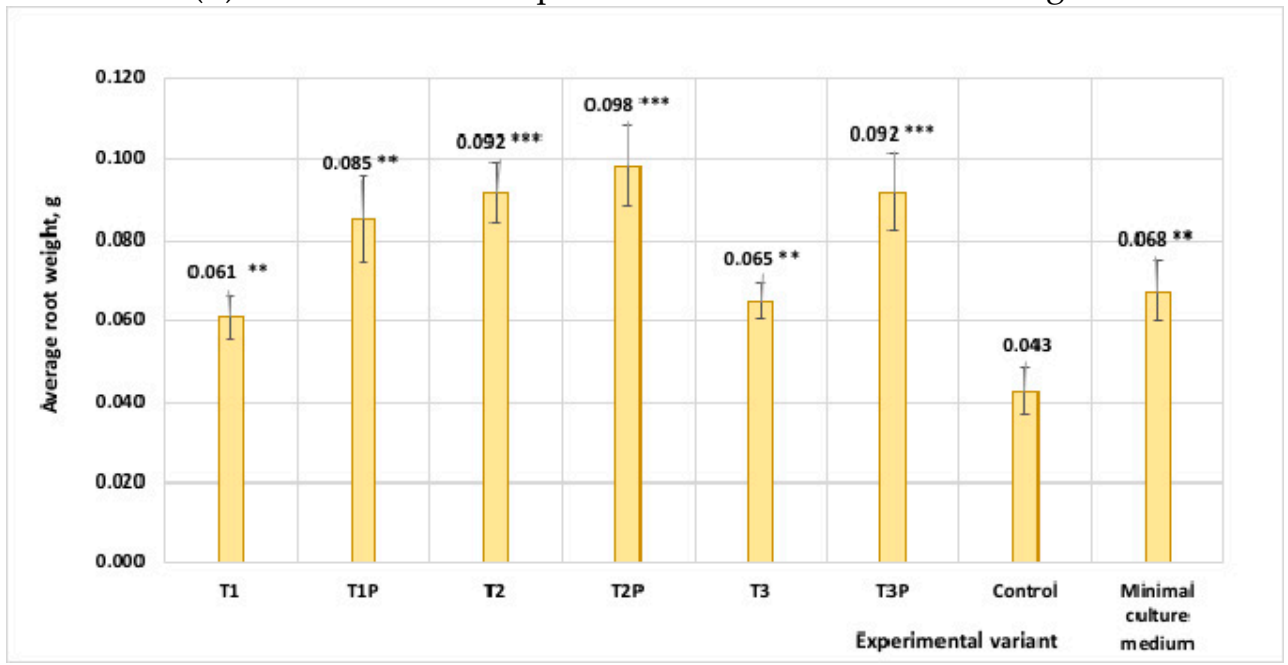

(c) The influence of experimental variants on roots weight

Figure 7. The influence of experimental variants on plants growth parameters. Measurements performed after 1 month of plants treatments with protein hydrolysates from Cladosporium isolates cultured on medium with or without feathers. * For $0.05<p<0.01=$ significant differences between the experimental variant and Control; notation: ${ }^{* *}$ for $0.01<p<0.005=$ distinct significant differences between the experimental variant and Control; notation: *** for $p<0.005=$ highly sig-nificant differences between the experimental variant and Control. 


\section{Discussion}

Since it is particularly desirable to assess the biocontrol ability of isolates, several tests were performed using in vitro dual culture test, the most common test used for the preliminary screening of biological control agents. Our Cladosporium T2 isolate was able to produce a relatively good percentage of inhibition, decreasing in the following order: $B$. allii $(86.4 \%)>$ S. sclerotiorum $(62.6 \%)>$ F. graminearum $(57.4)>R$. solani $(56.9 \%)$, which is a positive feature for future applications (Figure 1, Table 1). The studied literature shows that the antagonistic activity of species from Cladosporium genus has been described in many reports. For instance, Cladosporium cladosporoides was efficient against Puccinia horiana, a microcyclic rust that affects many Chrysanthemum species, which recommends it for an integrated management scheme applied in horticulture, especially to chrysanthemum cultivation [38]. Additionally, Cladosporium has been found to inhibit the growth of Colletotrichum acutatum by producing black spot of strawberry, or Colletotrichum fragariae that infects strawberries, and Colletotrichum gloeosporioides affecting many tropical fruits [39]. The antagonistic capability of $C$. tenuissimum was confirmed by inhibiting the germination of propagules of other rust fungi, as Peridermium pini and Cronartium flaccidum [40], and, also the germination and mycelial growth of several fungi like, Alternaria alternata, Botrytis cinerea, Mucor sp., Rhizoctonia solani [41]. The bioactive substances produced by Cladosporium cladosporioides are used to control the Aspergillus ochraceus, A. niger, Fusarium sp., Penicillium sp [42] which cause major damage to coffee crops. Furthermore, C. cladosporioides has been shown to be a potent entomopathogenic fungus and therefore a potential candidate for biocontrol of insect pests [43].

The performance when using fungal strains as a biological control is connected to different levels of expression of hydrolytic enzymes, as keratinases, cellulases and chitinases. In some cases, hydrolytic enzymes of beneficial microorganisms may act against the fungal cell walls of pathogens. Keratinases are proteolytic enzymes that can catalyze the cleavage and hydrolysis of the highly stable and fibrous proteins: keratins. Cellulases are a complex group of three major enzymes (exoglucanases, endoglucanases, and $\beta$-glucosidase), playing an important role in the hydrolysis of lignocellulosic materials. Chitinases are glycosyl hydrolases which degrade $\beta$-1, 4-linked insoluble linear polymers of $N$-acetylglucosamine (chitin) directly to low molecular weight chitooligomers. It is considered that fungal chitinolytic enzymes are demonstrated to be the most effective agents as different biological control of plant infections or diseases. In our experiments. Cladosporium isolate T2 was the most active in producing hydrolytic enzymes, followed in decreasing order by T3 isolate, and the last displaying T1 isolate. The characterization of hydrolytic enzymes could be considered a useful tool for the selection, together with other parameters, of the best isolates for biological purposes. This is another characteristic that supports the definition of T2 isolate as a good candidate as plant biostimulant. Similar behavior has been reported for another Cladosporium strains. Thus, it was found that a Cladosporium isolated from garden soil secretes a high level of hydrolytic enzymes (lipases, proteases and DNAses), useful for the formulation of a detergent [44]. Several endophytic of Cladosporium genus isolated from different medicinal plants have been evaluated for enzymatic activities such as amylase, protease, cellulose, and lipase, showing a high potential for clinical microbiology and therapeutic applications [45].

Many studies highlight the important antifungal role of VOCs compounds produced by fungal species. The compounds belong to different microbial chemical classes including acids, alcohols, aldehydes, aromatics, esters, hetero-cycles, ketones, terpenes, thiols, the composition being variable in relation with fungal type and environment factors. These compounds are involved in the regulation of symbiotic associations and in the distribution of saprophytic and mycorrhizal organisms due to their features, as low molecular weight, high vapor pressure, low boiling point and a lipophilic moiety [46,47]. Also, the secreted VOCs are important as a defense weapon against pathogens, inhibiting or reducing their activities, penetrating through soil pores [48]. Volatiles emitted by Cladosporium cladosporioides CL-1 have significantly improved the tobacco growth [49]. The test carried out with 
Cladosporium isolates in a Magenta vessel indicated several differences between isolates, Cladosporium $\mathrm{T} 2$ isolate determined the highest values of plants growth parameters due to volatile substances (Figure 2). The volatile substances from isolate T2 positively affect the plant growth indicating a useful feature of fungal isolate as plant promoting agent.

In the next experiment was evaluated the production of phytohormones, namely, 3 -indole acetic acid, which has a significant role in plant growth and development. IAA is normally produced by several bacterial and fungal species, regulating the physiological response and gene expression in these organisms. Recent studies demonstrate the involvement of IAA in plant-pathogen interactions, such as pathogenesis and defense mechanisms [50-52]. Generally, the culture medium to produce IAA is supplemented with L-tryptophan as a precursor, meanwhile, there are fungal isolates that produced IAA in the absence of exogenous tryptophan. The positive result for our isolates T2 and T3 is considered profitable for the environment and for field crops, due to the presence of tryptophan in plant exudates that are associated with endophytic Cladosporium.

There are many studies showing that the ability of endophytic fungi to solubilize phosphate and zinc contributes decisively to their use as agents to promote plant growth [53,54]. Zinc is an essential micronutrient for microorganism and plants, and its deficiency in soil affects significant crop yields and quality in agriculture, retarding shoot growth, decreases leaf size, modifying the susceptibility to biotic and abiotic stresses, decreasing water uptake and transport [55]. Among our Cladosporium isolates, qualitative tests for zinc solubilizing showed that T2 isolate was the most active as compared to T1 and T3 isolates (Figure 5a).

Phosphate solubilization by microorganisms is a process that contributes to the growth and development of plants. Generally, the inorganic phosphorus in soil is present as crystalline unstructured calcium, aluminum, and iron phosphates. Microorganisms produce organic acids that lower the $\mathrm{pH}$ of environment, facilitating the exchange of cations (iron, calcium, aluminum) from insoluble phosphates to potassium or sodium, which are phosphates soluble salts [56]. Our fungal isolates were all active, with qualitative test image indicating almost the same decolorization zone for all of them (Figure 5b).

A special attention was directed to the nitrogen content of PHs used in the treatment of tomato seedlings. Nitrogen is an essential macro element, acting as key catalyst to support photosynthesis and other important biochemical reactions required for healthy plant growth. As we expected, supplementing the fungal culture medium with feathers increased the amount of nitrogen in PHs intended for plants treatment. As a consequence, PHs from Cladosporium T2 isolate grown on medium with 1\% feathers had the highest amount of total nitrogen, and ammonium nitrogen, compared to other isolates (Table 5).

In pot experiments, treatment with PHs from Cladosporium isolates have beneficial effects on growth and development of plants, compared to those treated with water or minimal medium (Figure 6, Table 6). Encouraging results have been obtained in pot experiments treating tomato seedlings with protein hydrolysates obtained from Cladosporium T2 isolate cultured on medium supplemented with $1 \%$ feathers. Similar results have been reported, according to which Cladosporium strains are good agents for stimulating plant growth $[27,38,49]$.

The combined analysis of the results from all tests provided important information about characteristics of Cladosporium isolate T2, which guided its application as plant biostimulants in agriculture after supplementary investigations.

\section{Conclusions}

Until few years ago, fungal endophytes are unjustly neglected although they present beneficial activities for agriculture and horticulture, being necessary a recognition and re-evaluation of their potential [57-59].

For this purpose, three Cladosporium isolates were analyzed for the potential to be used as plant growth promoting agents. The studied characteristics, such as secretion of volatile organic compounds, the biocontrol against several aggressive phytopathogens, phosphate and zinc solubilization activities, the production of plant hormones, the secretion 
of hydrolytic enzymes and the effects on plants growth in pot experiments revealed that Cladosporium isolate $\mathrm{T} 2$ is a promising biostimulating agent with beneficial effect on crop cultures.

Our findings indicate that application of protein hydrolysates from Cladosporium isolate can serve as a promising approach for sustainable agriculture, as well as for the recovery of keratin wastes, abundant and cheap nitrogen-rich sources. Further studies are needed to optimize the Cladosporium cultivation on feathers based medium for higher nitrogen levels in protein hydrolysates, extension to field experiments, and, a very important issue, to evaluate the adverse effects (if any) on other crops, in humans or animals.

Author Contributions: L.J., I.R. and M.C. conceived and designed the experiments; M.C., I.R., L.C. and A.-M.G. performed the experiments; L.J., M.D. and N.R. analyzed the data; L.J., I.R. and M.C. wrote the paper; L.J., M.D. and N.R. reviewed and edited. All authors have read and agreed to the published version of the manuscript.

Funding: The work on this paper was supported by the Government of Romania, Ministry of Research, Innovation and Digitalization, project PN.19.23.01.01/2019.

Acknowledgments: The authors thank to Ministry of Research, Innovation and Digitalization of Romania, projects MANUNET-NITRISENS no 216/2020 and PN-III-P2-2.1-PED-2019-0991/PED 392/2020.

Conflicts of Interest: The authors declare no conflict of interest.

\section{References}

1. Archard, P.; Genschik, P. Releasing the brakes of plant growth: How GAs shutdown DELLA proteins. J. Exp. Bot. 2009, 60, 1085-1092. [CrossRef] [PubMed]

2. Hamayun, M.; Khan, S.A.; Ahmad, N.; Tang, D.-S.; Kang, S.-M.; Na, C.-I.; Sohn, E.-Y.; Hwang, Y.-H.; Shin, D.-H.; Le, B.-H.; et al. Cladosporium sphaerospermum as a new plant growth-promoting endophyte from the roots of Glycine max (L.) Merr. World J. Microbiol. Biotechnol. 2009, 25, 627-632. [CrossRef]

3. Hamayun, M.; Khan, S.A.; Khan, A.L.; Rehman, G.; Kim, Y.H.; Iqbal, I.; Hussain, J.; Sohn, E.-Y.; Lee, I.-J. Gibberellin production and plant growth promotion from pure cultures of Cladosporium sp. MH-6 isolated from cucumber (Cucumis sativus L.). Mycologia 2010, 102, 989-995. [CrossRef] [PubMed]

4. Almatar, M.; Makky, E.A. Cladosporium cladosporioides from the perspectives of medical and biotechnological approaches. 3 Biotech 2016, 6, 4. [CrossRef]

5. Uma, C.; Gomathi, D.; Ravikumar, G.; Kalaiselvi, M.; Palaniswamy, M. Production and properties of invertase from a Cladosporium cladosporioides in SmF using pomegranate peel waste as substrate. Asian Pac. J. Trop. Biomed. 2012, 2, S605-S611. [CrossRef]

6. Rashmi, R.; Siddalingamurthy, K.R. Cladosporium tenuissiumum-A new producer of xyloglucanase -specific endoglucanase. Int. J. Pharm. Bio. Sci. 2013, 4, 1291-1297.

7. Hariharan, P.; Chandrashekhar, N.; Pooja Vajpaye, S.; Srinivasa, K. Production, purification and characterization of thrombolytic enzyme from Cladosporium spp. through solid state fermentation. Int. J. Eng. Res. Technol. 2014, 3, 585-589.

8. Guan, G.Q.; Zhao, P.X.; Zhao, J.; Wang, M.J.; Huo, S.H.; Cui, F..; Jiang, J.X. Production and Partial Characterization of an Alkaline Xylanase from a Novel Fungus Cladosporium oxysporum. Hindawi Publishing Corporation. BioMed Res. Int. 2016, 4575024. [CrossRef]

9. Jakovljevic, V.D.; Vrvic, M.M. Potential of pure and mixed cultures of Cladosporium cladosporioides and Geotrichum candidum for application in bioremediation and detergent industry. Saudi J. 2018, 25, 529-536. [CrossRef] [PubMed]

10. Ademakinwa, N.A.; Agboola, F.K. Production of Laccase by Auerobasidium pullulans and Cladosporium werneckii under optimized conditions: Applications in decolourization of textile dye. Res. Rev: J. Microbiol. Biotechnol. 2014, 3, 32-40.

11. Nwadiaro, P.; Ogbonna, A.; Ponchang, W.; Adekojo, D. Keratinolytic activity of Cladosporium and Trichoderma species isolated from barbers' landfill. Int. J. Biosci. 2015, 6, 104-115.

12. Cavello, I.A.; Chesini, M.; Hours, R.A.; Cavalitto, S.F. Study of the production of alkaline keratinases in submerged cultures as an alternative for solid waste treatment generated in leather technology. J. Microbiol. Biotechnol. 2013, 23, 1004-1014. [CrossRef] [PubMed]

13. Xu, L; Geelen, D. Developing Biostimulants from Agro-Food and Industrial By-Products. Front. Plant Sci. 2018, 9, 1567. [CrossRef] [PubMed]

14. Vasconcelos, A.C.F.; Chaves, L.H.G. Biostimulants and Their Role in Improving Plant Growth under Abiotic Stresses. IntechOpen 2019. [CrossRef]

15. Rouphael, Y.; Colla, G. Editorial: Biostimulants in Agriculture. Front. Plant. Sci. 2020, 11, 40. [CrossRef]

16. Bulgari, R.; Franzoni, G.; Ferrante, A. Biostimulants Application in Horticultural Crops under Abiotic Stress Conditions. Agronomy 2019, 9, 306. [CrossRef] 
17. Menon, S.; Savur, B.; Kasat, D.; Movani, U.; Singh, S.; Rane, M. Management and utilization of Keratin Waste-A review. Int. J. Adv. Res. Ideas Innov. Technol. 2020, 6, 511-515.

18. Šafari, R.; Zemlji, L.F.; Novak, M.; Dugonik, B.; Bratina, B.; Gubeljak, N.; Bolka, S.; Strnad, S. Preparation and Characterisation of Waste Poultry Feathers Composite Fibreboards. Materials 2020, 13, 4964. [CrossRef]

19. Seidavi, A.R.; Zaker-Esteghamati, H.; Scanes, C.G. Present and potential impacts of waste from poultry production on the environment. Worlds Poult. Sci. J. 2019, 75, 29-42, Cambridge University Press. [CrossRef]

20. Kodak, S.; Gharge, T.; Chavan, V.; Sibi, G. Microbial Degradation of Poultry Feather Wastes under the Influence of Temperature and pH-A Review. Int. J. Environ. Sci. Nat. Res. 2019, 21, 556063. [CrossRef]

21. He, Z.; Sun, R.; Tang, Z.; Bu, T.; Wu, Q.; Li, C.; Chen, H. Biodegradation of Feather Waste Keratin by the Keratin-Degrading Strain Bacillus subtilis 8. J. Microbiol. Biotechnol. 2018, 28, 314-322. [CrossRef]

22. Joardar, J.C.; Rahman, M.M. Poultry feather waste management and effects on plant growth. Int. J. Recycl. Org. Waste Agric. 2017, 7, 183-188. [CrossRef]

23. Brandelli, A.; Sala, L.; Kalil, J. Microbial enzymes for bioconversion of poultry waste into added-value products. Food Res. Int. 2015, 73, 3-12. [CrossRef]

24. Ghaffar, I.; Imtiaz, A.; Hussain, A.; Arshad Javid, A.; Jabeen, F.; Akmal, M.; Qaz, J.I. Microbial production and industrial applications of keratinases: An overview. Int. Microbiol. 2018, 21, 163-174. [CrossRef]

25. Akpor, O.B.; Odesola, D.E.; Thomas, R.E.; Oluba, O.M. Chicken feather hydrolysate as alternative peptone source for microbial cultivation. F1000Research 2019, 7, 1918. [CrossRef] [PubMed]

26. Islam, M.A.; Nain, Z.; Alam, M.K.; Banu, N.A.; Islam, M.R. In vitro study of biocontrol potential of rhizospheric Pseudomonas aeruginosa against Fusarium oxysporum f. sp. Cucumerinum. Egypt. J. Biol. Pest Control 2018, 28, 90. [CrossRef]

27. Li, Z.T.; Wojciech, J.J.; Zongrang, L.; Callahan, A.M.; Breyn, E.E.; Wayne, J.M.; Chris, D. Exposure in vitro to an Environmentally Isolated Strain TC09 of Cladosporium sphaerospermum Triggers Plant Growth Promotion, Early Flowering, and Fruit Yield Increase. Front. Plant. Sci. 2019, 9, 1959. [CrossRef]

28. Agrawal, T.; Kotasthane, A.S. Chitinolytic assay of indigenous Trichoderma isolates collected from different geographical locations of Chhattisgarh in Central India. SpringerPlus 2012, 1, 73. [CrossRef] [PubMed]

29. Yoon, J.H.; Park, J.E.; Dong, Y.S.; Hong, S.B.; Ko, S.J.; Kim, S.H. Comparison of dyes for easy detection of extracellular cellulases in fungi. Mycobiology 2007, 35, 21-24. [CrossRef] [PubMed]

30. Lateefa, A.; Adelerea, I.A.; Gueguim-Kana, B.E.B. Bacillus safensis LAU 13: A new source of keratinase and its multi-functional biocatalytic applications. Biotechnol. Biotechnol. Equip. 2015, 29, 5463. [CrossRef]

31. Gordon, S.A.; Weber, R.P. Colorimetric estimation of indole acetic acid. Plant Physiol. 1951, 26, 192-195. [CrossRef]

32. Gutierrez, C.K.; Matsuy, G.Y.; Lincoln, D.E.; Lovel, C.R. Production of the phytohormone indole-3 acetic acid by the estuarine spesies of the genus Vibrio. Appl. Environ. Microbiol. 2009, 75, 2253-2258. [CrossRef]

33. Sharma, S.K.; Sharma, M.P.; Ramesh, A.; Joshi, O.P. Characterization of Zinc-Solubilizing Bacillus Isolates and their Potential to Influence Zinc Assimilation in Soybean Seeds. J. Microbiol. Biotechnol. 2012, 22, 352-359. [CrossRef]

34. Vazquez, P.; Holgui, G.; Puente, M.E.; Lopez-Cortes, A.; Bashan, Y. Phosphate-solubilizing microorganisms associated with the rhizosphere of mangroves in a semiarid coastal lagoon. Biol. Fertil. Soils 2000, 30, 460-468. [CrossRef]

35. Guo, W.S.; Ren, L.P.; Zhou, Z.M.; Meng, Q.X. Difference of nitrogen contents determined by the combustion and Kjeldahl method in response to nitrate nitrogen in some feedstuffs. J. Anim. Feed Sci. 2007, 16 (Suppl. 2), 178-183. [CrossRef]

36. Cavello, I.A.; Crespo, J.M.; García, S.S.; Zapiola, J.M.; Luna, M.F.; Cavalitto, S.F. Plant growth promotion activity of keratinolytic fungi growing on a recalcitrant waste known as (hair waste). Biotechnol. Res. Int. 2015, 952921. [CrossRef]

37. Lee, S.; Yap, M.; Behringer, G.; Hung, R.; Bennett, J.W. Volatile organic compounds emitted by Trichoderma species mediate plant growth. Fungal Biol. Biotechnol. 2016, 3, 7. [CrossRef] [PubMed]

38. Torres, D.E.; Rojas-Martinez, R.I.; Zavaleta-Mejia, E.; Guevara-Fefer, P.; Marquez-Guzman, G.J.; Perez-Martinez, C. Cladosporium cladosporioides and Cladosporium pseudocladosporioides as potential new fungal antagonists of Puccinia horiana Henn., the causal agent of chrysanthemum white rust. PLoS ONE 2017, 12, e0170782. [CrossRef] [PubMed]

39. Wang, X.; Radwan, M.; Tarawneh, A.; Gao, J.; Wedge, D.; Rosa, L.; Cutler, H.G.; Cutler, S.J. Antifungal activity against plant pathogens of metabolites from the endophytic fungus Cladosporium cladosporioides. J. Agric. Food Chem. 2013, 61, 4551-4555. [CrossRef]

40. Moricca, S.; Ragazzi, A.; Mitchelson, K.R.; Assante, G. Antagonism of the two needle pine stem rust fungi Cronartium flaccidum and Peridermium pini by Cladosporium tenuissimum in vitro and in planta. Phytopathology 2001, 91, 457-468. [CrossRef] [PubMed]

41. Moricca, S.; Ragazzi, A.; Assante, G. Biocontrol of Rust Fungi by Cladosporium tenuissimum. In Rust Diseases of Willow and Poplar; A4913:AMA:Pei:First Proofs: 17-Nov-2004; Pei, M.H., McCracken, A.R., Eds.; @CAB International: Wallingford, UK, 2005; pp. 213-229. [CrossRef]

42. Chalfoun, S.M. Biological control and bioactive microbial metabolites: A coffee quality perspective. Cienc. Agrotec. 2010, 34, 1071-1085. [CrossRef]

43. Islam, T.; Gupta, D.R.; Surovy, M.Z.; Mahmud, N.U.; Mazlan, N. Identification and application of a fungal biocontrol agent Cladosporium cladosporioides against Bemisia tabaci. Biotechnol. Biotechnol. Equip. 2019, 33, 1698-1705. [CrossRef] 
44. Acosta, M.B.R.; De Santa Inez, D.C.; Balieiro, L.F.; Mano, E.T.; da Silva, L.F. Hydrolytic enzymes (DNAses, lipases and proteases) secreted by Cladosporium cladosporioides isolated from soil and its potential application in biotechnology. Rev. Soc. Ven. Microbiol. 2017, 37, 61-65.

45. Patil, M.G.; Pagare, J.; Patil, S.N.; Sidhu, A.K. Extracellular Enzymatic Activities of Endophytic Fungi Isolated from Various Medicinal Plants. Int. J. Curr. Microbiol. App. Sci. 2015, 4, 1035-1042.

46. Schulz-Bohm, K.; Sánchez, M.L.; Garbeva, P. Microbial Volatiles: Small Molecules with an Important Role in Intra- and InterKingdom Interactions. Front. Microbiol. 2017, 8, 2484. [CrossRef]

47. Schmidt, R.; Jager, V.; Zühlke, D.; Wolff, C.; Bernhardt, J.; Cankar, K.; Beekwilder, J.; van Ijcken, W.; Sleutels, F.; de Boer, W.; et al. Fungal volatile compounds induce production of the secondary metabolite Sodorifen in Serratia plymuthica PRI-2. Sci. Rep. 2017, 7, 862. [CrossRef] [PubMed]

48. Kaddes, A.; Fauconnier, M.L.; Sassi, K.; Nasraoui, B.; Jijakli, M.H. Endophytic Fungal Volatile Compounds as Solution for Sustainable Agriculture. Molecules 2019, 24, 1065. [CrossRef]

49. Diby, P.; Park, K.S. Dentification of Volatiles Produced by Cladosporium cladosporioides CL-1, a Fungal Biocontrol Agent That Promotes Plant Growth. Sensors 2013, 13, 13969-13977. [CrossRef]

50. Kumla, J.; Suwannarach, N.; Matsui, K.; Lumyong, S. Biosynthetic pathway of indole-3-acetic acid in ectomycorrhizal fungi collected from northern Thailand. PLoS ONE 2020, 15, e0227478. [CrossRef]

51. Fu, S.F.; Wei, J.Y.; Chen, H.W.; Liu, Y.Y.; Lu, H.Y.; Chou, J.Y. Indole-3-acetic acid: A widespread physiological code in interactions of fungi with other organisms. Plant Signal. Behav. 2015, 10(8), e1048052. [CrossRef]

52. Egamberdieva, D.; Wirth, S.J.; Alqarawi, A.A.; Abd Allah, E.F.; Hashem, A. Phytohormones and Beneficial Microbes: Essential Components for Plants to Balance Stress and Fitness. Front. Microbiol. 2017, 8, 2104. [CrossRef]

53. Khan, A.L.; Hamayun, M.; Kang, S.M.; Kim, Y.H.; Jung, H.Y.; Lee, J.H.; Lee, I.J. Endophytic fungal association via gibberellins and indole acetic acid can improve plant growth under abiotic stress: An example of Paecilomyces formosus LHL10. BMC Microbiol. 2012, 12, 3. [CrossRef]

54. Waqas, M.; Khan, A.L.; Lee, I.J. Bioactive chemical constituents produced by endophytes and effects on rice plant growth. J. Plant Interact. 2014, 9, 478-487. [CrossRef]

55. Ku, Y.S.; Rehman, H.M.; Lam, H.M. Possible Roles of Rhizospheric and Endophytic Microbes to Provide a Safe and Affordable Means of Crop Biofortification. Agronomy 2019, 9, 764. [CrossRef]

56. Adhikari, P.; Pandey, A. Phosphate solubilization potential of endophytic fungi isolated from Taxus wallichiana Zucc. roots. Rhizosphere 2019, 9, 2-9. [CrossRef]

57. Lugtenberg, B.J.J.; Caradus, J.R.; Johnson, L.J. Fungal endophytes for sustainable crop production. FEMS Microbiol. Ecol. 2016, 92, fiw194. [CrossRef] [PubMed]

58. Manganyi, M.C.; Ateba, C.N. Untapped Potentials of Endophytic Fungi: A Review of Novel Bioactive Compounds with Biological Applications. Microorganisms 2020, 8, 1934. [CrossRef] [PubMed]

59. Omomowo, O.I.; Babalola, O.O. Bacterial and Fungal Endophytes: Tiny Giants with Immense Beneficial Potential for Plant Growth and Sustainable Agricultural Productivity. Microorganisms 2019, 7, 481. [CrossRef] [PubMed] 